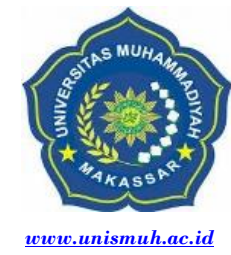

www.unismuh.ac.id
Jurnal Equilibrium Pendidikan Sosiologi

Vol V Mei No. 12017

\title{
Musik Kesenian Tradisional Parrawana pada Era Modernisasi di Polewali Mandar
}

\author{
Syaribulan $\mathrm{K}$ \\ Universitas Muhammadiyah Makassar \\ syaribulank@unismuh.ac.id
}

\begin{abstract}
The existence of traditional art music parrawana in the era of modernization. This research uses qualitative descriptive approach supported by femonology approach through purposive sampling technique. Data collection is used by observation, interview, and documentation. The categories of informants used were key informants, key informants, and additional informants. Technique validity technique triangulation data, triangulation time and triangulation of data source. The results can be concluded that the existence of art Parrawana in the era of modernization according to the tradition of the ancestors and not affected by the flow of modernization is always demanding development. Although Polewali Mandar people have known modernization in their changing lives and mindset have been following the times, but they still maintain the preservation of traditional art as inherited by the ancestors in the era of modernization. Efforts made by the community, community and government is to invite young people to preserve the arts Parrawana.
\end{abstract}

Keywords: Music, Parrawana, Modernization

\begin{abstract}
Abstrak. Eksistensi musik kesenian tradisional parrawana di era modernisasi. Penelitian ini menggunakan pendekatan deskriptif kualitatif yang ditunjang dengan pendekatan femonologi melalui teknik purposive sampling. Pengumpulan data digunakan dengan cara observasi, wawancara, serta dokumentasi. Kategori informan yang digunakan yaitu informan kunci, informan utama, dan informan tambahan. Teknik keabsahan data triangulasi teknik, triangulasi waktu serta triangulasi sumber data. Hasil penelitian dapat disimpukan bahwa eksistensi kesenian Parrawana dalam era modernisasi sesuai tradisi nenek moyang dan tidak terpengaruh oleh arus modernisasi yang selalu menuntut perkembangan. Walaupun masyarakat Polewali Mandar telah mengenal modernisasi dalam perubahan kehidupan dan pola pikir mereka telah mengkuti perkembangan jaman, akan tetapi mereka tetap menjaga kelestarian kesenian tradisional seperti yang diwariskan leluhur di era modernisasi. Upaya yang dilakukan oleh masyarakat, paguyuban dan pemerintah adalah dengan mengajak generasi muda untuk melestarikan kesenian Parrawana.
\end{abstract}

Kata Kunci: Musik, Parrawana, Modernisasi 


\section{PENDAHULUAN}

Kesenian Indonesia memiliki beraneka ragam bentuk yang memiliki cirri khas masing-masing. Setiap daerah di Indonesia memiliki adat istiadat, dan wilayah tersendiri hingga membentuk kesenian tradisional yang berbeda dengan daerah lainnya. Dengan beragamnya kondisi Indonesia ini membentuk Indonesia sebagai Negara yang multikultural, yang kaya akan budaya. Makna dalam sebuah kesenian dapat berubah-ubah sesuai dengan perkembangan zamannya dan sesuai orang yang memaknainya. Dalam perkembangan zaman, keberadaan suatu kesenian tradisional mengalami kemerosotan. Banyak kesenian tradisonal yang sudah jarang muncul ke publik. Pada pengaruh era modernisasi sekarang ini tidak banyak generasi muda yang giat belajar kesenian daerah, mereka lebih terpengaruh arus perkembangan zaman. Kebanyakan generasi muda lebih memilih belajar nge-dance bahkan boyband.

Modernisasi tidak hanya milik masyarakat yang bermukim di daerah perkotaan saja, sekarang ini sentuhan-sentuhan modernisasi telah menjalar ke berbagai pelosok daerah begitu pula yang terjadi di Kabupaten Polewali Mandar, kehidupan masyarakat telah mengikuti perkembangan zaman sesuai sesuai konteks masa sekarang. Sesuatu yang terus menerus berubah. Sehingga begitu banyak perubahan-perubahan yang terjadi baik itu dilihat dari kehidupan masyarakatnya maupun dari segi tradisi khususnya musik kesenian yang terdapat di Polewali Mandar.

Pada zaman dahulu, pertunjukan kesenian tradisional sangat diminati oleh para masyarakat. Pertunjukan kesenian tidak hanya menjadi tontonan tetapi juga tuntutan karena di dalam pementasan ini akan diperoleh pesan-pesan moral. Tetapi seiring dengan perkembangan zaman, dengan masuknya budaya luar ke budaya sendiri menjadikan krisis budaya bagi budaya kita sendiri. Dengan masuknya budaya luar. Disadari bahwa hal itu menggeser minat masyarakat akan budaya daerahnya. Bahkan berpengaruh pada pelestarian kesenian tradisional masing-masing daerah.

\section{METODE PENELITIAN}

Penelitian ini menggunakan penelitian kualitatif yang bersifat deskriptif ditunjang dengan pendekatan studi kasus. Teknik pengambilan sampel yang digunakan dalam penelitian ini secara purposive sampling. Dimana purposive sampling adalah dengan memilih secara langsung informan atau responden berdasarkan kriteria atau yang diperkirakan dapat menjawab atau memberikan informasi mengenai apa yang dibutuhkan peneliti. Kategori informan yang digunakan dalam penelitian ini yaitu informan kunci, informan utama, dan informan tambahan melalui teknik keabsahan data yaitu triangulasi teknik, triangulasi waktu serta triangulasi sumber data. Adapun fokus penelitian ini yaitu eksistensi musik kesenian tradisional di era modernisasi. Dalam instrumen penelitian, yang menjadi instrumen utama adalah peneliti sendiri dengan menggunakan alat bantu berupa pedoman wawancara, observasi, sumber dokumen, dokumentasi (kamera) serta personal computer (PC). Teknik yang digunakan untuk memperoleh atau mengumpulkan data yang dibutuhkan dalam penelitian ini menggunakan teknik pengumpulan data observasi, wawancara,serta dokumentasi. Analisis data melalui data yang diperoleh dari teknik pengumpulan data, dengan cara menyusun, mengedit, mengklasifikasi kemudian menguraikan untuk mendapatkan kesimpulan.

\section{PEMBAHASAN}

Parrwana yang lahir pada zaman dahulu merupakan media dakwah saja. Tetapi, pada saat ini musik kesenian parrawana tidak lagi berfungsi sebagaimana awalnya namun telah menjadi sebuah musik kesenian yang mandiri. Karena perubahan zaman dan situasi serta masuknya beberapa anggota baru yang membawa ide segar dari luar membuat parrawana di Kabupaten Polewali Mandar berkembang dan berevolusi mengikuti perkembangan eranya. Dalam aksi teatrikal setiap kelompok musik kesenian parrawana mempunyai perbedaan dan ciri khas masing-masing namun secara garis besar pertunjukan musik kesenian parrawana ini selalu dibuka dengan atraksi-atraksi 
seperti menari dan bernyanyi mengikuti irama tabuhan rebana.

Puncak dari musik kesenian parrawana yang paling digemari adalah disaat mereka menari mengikuti tabuhan rebana, serta terkadang pula terdapat anak-anak kecil yang berdiri diantara para parrawana untuk menari yang biasa disebut pa'denggoq. Dimana tarian denggoq ini dilakukan secara berpasangan dengan memainkan kedua tanggannya yang sedang memegang sebuah alat, dengan gerakan yang dinamis dan mata yang bergerak-gerak yang kadang mengundang gelak tawa para penonton.

Adapun perkembangan musik kesenian parrawana di Kabupaten Polewali Mandar saat ini. Seperti yang kita ketahui bahwa Indonesia adalah negara yang kaya akan sumber daya alam serta memiliki banyak budaya yang bermacam-macam seperti budaya yang berkembang di wilayah Sulbar terutama di Kabupaten Polewali Mandar ini yaitu musik kesenian parrawana. Kesenian tidak hanya sebagai hiburan semata tetapi lebih pada menunjukkan nilai yang lebih yakni kesenian merupakan wadah inspirasi intelektual masyarakat. Musik kesenian parrawana sempat mengalami surut perkembangannya pada masa modern saat ini karena banyaknya orang yang mengatakan bahwa musik kesenian tradisional ini sudah kuno terutama pada kalangan pemudapemudi di Kabupaten polewali Mandar, serta lebih memilih mempelajari sesuatu yang baru dan telah mengikuti perubahan mode saat ini. Pelaku musik parrawana ini tidak patah arang dan buang handuk, berbagai macam cara dilakukan untuk melestarikan musik kesenian tradisional ini.

Pada era Modernisasi saat ini dengan banyaknya cara yang telah dilakukan oleh para seniman-seniman musik kesenian parrawana di Kabupaten Polewali Mandar, eksistensi musik kesenian parrawana mulai nampak seiring dengan adanya kebebasan berekspresi, hal ini terbukti dengan semakin seringnya musik Parrawana ini ditampilkan dalam berbagai acara seperti iringiringan pernikahan, ruwat Desa, karnaval daerah, pelantikan kepala Desa, festival-festival budaya, pawai budaya HUT Polewali Mandar di kantor Gubernuran Polewali Manda, dan festivalfestival kesenian lainnya. Menyadari pentingnya kesenian sebagai khasanah budaya bangsa yang harus dilestarikan karena nantinya akan menjadi warisan bagi anak cucu karena mereka juga berhak tahu bahwa nenek moyangnya merupakan bangsa yang kreatif, berbudaya dan peduli akan kelestarian budayanya. Selain itu peran dari Pemerintah Kabupaten Dinas Pemuda Olahraga, Kebudayaan, dan Pariwisata Kabupaten Polewali Mandar terus mengembangkannya

Sebagai kesenian asli dari Sulawesi Barat. Dibuktikan dengan terbentuknya grup-grup parrawana yang semakin hari semakin banyak, seperti yang telah didirikan oleh $\mathrm{Hj}$. Cammana parrawana Towaine yang telah merekrut banyak sekali anggota baik yang tua maupun yang masih anak-anak. Musik kesenian parrawana memiliki gerak yang sederhana serta merupakan hasil manusia yang mengungkapkan ekspresi lewat gerak suara atau bunyi-bunyian. Masyarakat Kabupaten Polewali Mandar lebih mengenal parrawana sebagai musik tradisi dan hasil karya seni warisan dari nenek moyang yang menjadi musik tradisi asli Sulawesi Barat ini yang telah dijadikan salah satu musik kesenian tradisional Kabupaten Polewali Mandar. Parrawana sebagai hasil karya seni digambarkan dalam bentuk gerakan menabuh rebana yang hingga sekarang baik di Kabupaten Polewali Mandar sendiri telah berdiri paguyupan seni bantengan yang di atur oleh masyarakat dan para pemuda setempat.

Parrawana di Kabupaten Polewali Mandar banyak memberikan kontribusi sendiri bagi pertumbuhan Sulawesi Barat, salah satu kontribusi yang di berikan oleh keberadaan musik parrawana di Kabupaten ini ialah semakin terkenal Sulawesi Barat sebagai rumah dari musik parrawana ini, banyak para pemuda Desa lain yang belajar dengan senior yang ada di Kabupaten Polewali Mandar sehingga dapat meningkatkan pendapatan Polewali Mandar.

\section{KESMPULAN}

a. Tradisi Parrawana di Kabupaten Polewali Mandar masih sangat eksis sampai sekarang, 
di tandai dengan seringnya parrawana di undang pada acara-acara yang di buat masyarakat setempat maupun acara-acara lain yang di adakan oleh warga desa lain maupun acara-acara besar lain yang langsung di undangan oleh pejabat daerah tersebut.

b. Tradisi parrawana banyak mengalami inovasi serta perubahan seiring dengan perkembangan zaman saat ini, perubahan yang dapat dilihat adalah dari segi kostum yang di pakai oleh para pemain parrawana serta atribut-atribut, ornamen serta tari yang mendukung pertunjukan ini.

c. Masyarakat atau pemain musik Parrwana di Kabupaten Polewali Mandar telah menyesuaikan parrawana dengan kehidupan era modern salah satu wujud perubahan yakni alat yang dipakai saat tampil yang dahulunya menggunakan rebana yang besar dan kecil sekarang telah ditambahi dengan alat-alat lain sebagai penunjang, hal ini untuk dapat lebih dapat menarik minat masyarakat. Perubahan yang lain adalah pernak-pernik yang dipakai oleh parrawana.

d. Masyarakat Kabupaten Polewali Mandar sangat membantu menjaga eksistensi tradisi musik Parrawana dengan turut serta menjadi pemain parrawana serta membantu melestarikan tradisi musik parrawana dengan membentuk kelompok patau grup-grup parrawana yang terorganisir dengan baik sampai sekarang.

\section{DAFTAR PUSTAKA}

[1] Garna Judistira. 1996. Ilmu-IImu Sosial Dasar-KonsepPosisi. Bandung: Program Pascasarjana Universitas Padjadjaran

[2] Martono, Nanang.2014. Sosiologi Perubahan Sosial Perspektif klasik Modern, postmodern, post kolonial. Jakarta:Rajawali Pers

[3] Kholif, Nur Hazin. 1994. Kamus Lengkap Bahasa Indonesia. Surabaya. Terbit Terang

[4] Tim Penyusun Program Studi Pendidikan Sosiologi Fkip Unismuh Makassar. 2015. Pedoman Penulisan Skripsi. Unismuh Makassar

[5] Goodman,Doughlas J dan Ritzer. George. ( 2011 ). Teori Sosiologi Modern. Terjemahan oleh Alimanda. Jakarta : Kencana Prenada Media Grup

[6] Scott Jhon ( 2012 ). Teori Sosial. Yogjakarta : Pustaka Pelajar
[7] Jazuli M. ( 2014 ). Sosiologi Seni Pengantar Dan Model Studi Seni Edisi 2. Yogyakarta.Graha IImu

[8] S.H. Suratma. ( 2013 . Ilmu Sosial Budaya Dasar. Malang. Intimedia

[9] Naskah Pengembangan Media Kebudayaan Jawa Timur. (1977). Sejarah Seni Budaya Jawa Timur. Jakarta: Proyek Pengembangan Media Kebudayaan Departemen Pendidikan Dan Kebudayaan )

[10] Maryati Kun, Suryawati Juju. (2008). SPM SMA DAN MA Siap Tuntas Menghadapi Ujian Nasional. Jakarta : Esis (Penebit Erlangga )

[11] Najah Naqib. (2015). Suku Mandar Pelaut Ulung Yang Kaya Pekerti. Makassar. Anggota IKAPI ( Ikatan Penerbit Indonesia ) Daerah Sulawesi Selatan.

[12] Syifa Lutfi. M, Maulana. (2014). Tradisi Bantengan Dan Modernisasi : Studi tentang Eksistensi Tradisi Bantengan Di Dusun Banong Desa Gebangsari Kecamatan Jatirejo Kabupaten Mojokerto. Thesis. Uin Sunan Ampel Surabaya.

[13] Permatasari Andrea Bella. (2014). Eksistensi Kesenian Incling Dalam Era Modernisasi ( Studi Kasus Di Desa Somongari Kecamatan Kaligesing Kabupaten Purworejo).Skripsi. Purworejo.

[14] Sugiono. (2009). Metode Penelitian Pendekatan Kuantitatif, kualitatif dan $R \& D$. Bandung: Alfa Beta

[15] Moleong, J.Lexy. (2007). Metodologi Penelitian Kualitatif. Bandung: Rosdakarya

[16] Raho, Bernard. (2007). Teori Sosiologi Modern. Jakarta: Prestasi Pustaka 